\title{
Coup d'État at the Age of Formation of the Early Modern State
}

\author{
S. E. Fyodorov, B. I. Kliuchko
}

For citation: Fyodorov S.E., Kliuchko B. I. Coup d'État at the Age of Formation of the Early Modern State. Vestnik of Saint Petersburg University. History, 2018, vol.63, issue 3, pp. 898-907. https://doi. org/10.21638/11701/spbu02.2018.314

In the 1980s the concept of "État moderne" gained more and more ground in the French historiography, and conventional statist concepts came in for severe criticism. The debate centred around not only general approaches concerning continuity of political processes from Antiquity to Modern times, but also around more specific issues, which, nevertheless, required serious reconsideration. With regard to this, the phenomenon of coup d'État and its interpretation in accordance with the development of État moderne is of exceptional interest. In the Early Modern time, there were no mechanisms of the dialogue between rulers and political communities. The absence of dialogue didn't mean the absence of conflict, therefore, the only remaining means of resolving such conflicts was political cataclysm (including a coup d'état), and it was absolutely ordinary and imperative in the existing framework at the time. In order to outline the main features of coups d'État during the period of genesis of État moderne, it's necessary to systematize this phenomenon and to consider concrete examples of this classification. The most frequent form of coups détat, and historically the first one at the time, was usurpation, which was quite natural - as the power was physically represented in the body of the sovereign. The second form of coups d'État typical of the period of the genesis of État moderne were extraordinary actions in the course of dynastic crises. The third form of coups d'etat in the period of the genesis of État moderne were coups disguised as the struggle against conspiracy.

Keywords: Early Modern Western Europe, Early Modern State, coup d’État.

\section{Государственные перевороты в эпоху формирования нового государства}

\section{С. Е. Федоров, Б. И. Ключко}

Для цитирования: Fyodorov S.E., Kliuchko B.I. Coup d'État at the Age of Formation of the Early Modern State // Вестник Санкт-Петербургского университета. История. 2018. Т. 63. Вып. 3. C. 898-907. https://doi.org/10.21638/11701/spbu02.2018.314

Сергей Егорович Федоров - д-р ист. наук, проф., Санкт-Петербургский государственный университет, Российская Федерация, 199034, Санкт-Петербург, Университетская набережная, 7-9; s.fedorov@spbu.ru

Sergey E. Fyodorov — Doctor in History, Professor, St. Petersburg State University, 7-9, Universitetskaya emb., St. Petersburg, 199034, Russian Federation; s.fedorov@spbu.ru

Борис Игоревич Ключко - кандидат исторических наук, Российская национальная библиотека, Российская Федерация, 191069, Санкт-Петербург, ул. Садовая, д. 18; boris-klyuchko@mail.ru

Boris I. Kliuchko - PhD, Russian National Library, 18, Sadovaya str., St. Petersburg, 191069, Russian Federation; boris-klyuchko@mail.ru

This article has been written with support from the Russian National Fund for the Humanities (RGHF) (grant N 16-01-00108a) and St. Petersburg State University (project No. 11517076)

() Санкт-Петербургский государственный университет, 2018 
После того как в 1980-х годах во французской историографии широкую популярность обрела концепция État moderne, традиционные этатисткие концепции были подвергнуты разрушительной критике. Полемика затронула не только общие подходы, касавшиеся преемственности политических процессов от античности до Нового времени, но и более частные проблемы, требовавшие, однако, серьезного переосмысления. Особый интерес в связи с этим представляют само явление государственных переворотов и его интерпретация с учетом логики становления État moderne. Концепт «coup d'État» появился в трактате Габриэля Нодэ «Considerations politiques sur les coups d'État». Он определял «соuр» как ситуацию, в которой правитель нарушает законы ради защиты публичных интересов. В этом же тексте появляется концепт «raison d'État», который определяется как «знание или наука о нужных средствах для основания сеньории, ее сохранения и увеличения». Соединение в одном тексте двух элементов, актуализирующих новое понимание функций и возможностей верховной власти, обусловило четкий разрыв между прежней и новой концепциями общественного блага. В раннее Новое время не существовало механизмов диалога правителей с политическим сообществом. Отсутствие диалога не означало отсутствия конфликтов, поэтому любой политический катаклизм (в том числе и государственный переворот) был единственным способом разрешения этих конфликтов, и в той системе координат он был абсолютно ординарен и необходим. В статье выделяются основные характеристики «государственного переворота» периода генезиса État moderne и приводится их классификация. Наиболее частым видом государственных переворотов и исторически первым в то время была узурпация. Вторым видом государственных переворотов, характерных для периода генезиса État moderne, были экстраординарные действия в ходе династических кризисов. Третьим видом государственных переворотов эпохи генезиса État moderne являются перевороты, замаскированные под борьбу с заговорами.

Ключевые слова: Западная Европа раннего Нового времени, новое государство, государственные перевороты.

In the 1980s the concept of "État moderne" gained more and more ground in the French historiography ${ }^{1}$, and conventional statist concepts came in for severe criticism. The debate centred around not only general approaches concerning continuity of political processes from Antiquity to Modern times, but also around more specific issues, which, nevertheless, required serious reconsideration. With regard to this, the phenomenon of coup d'état and its interpretation in accordance with the development of État moderne is of exceptional interest ${ }^{2}$.

${ }^{1}$ Since then, an international group of scholars headed by Jean-Philippe Genet has been engaged in researching the genesis of the concept of l'État moderne. See: Genèse de l'État Moderne. Prélèvement et Redistribution / éd par. J.-P. Genet, M. Le Mené. Paris, 1987; État et Église dans la Genèse de l'État Moderne / éd par J.-P. Genet, B. Vincent. Madrid, 1986; La Ville, la Bourgeoisie et la Genèse de l'État Moderne XIIe XVIIIe siècles: actes du colloque de Bielefeld, 29 novembre - 1er décembre 1985 / éd. par J.-P.Genet, N. Bulst. Paris, 1988; L’État Moderne: Genèse, bilans et perspectives / éd. par J.-P. Genet. Paris, 1990; L'État moderne: le droit, lespace et les formes de l'État / éd. par J.-P. Genet et N. Coulet. Paris, 1990; Visions sur le développement des États Européens. Théories et historiographies de l'État Moderne / éd. par J.-P. Genet, W. Blockmans. Rome, 1993; L'État Moderne et les Élites, XIIIe - XVIIIe siècles. Apports et limites de la méthode Prosopographique / éd. par J.-P. Genet, G. Lottes. Paris, 1996; Genet J.-P. La Genèse de l'État moderne Culture et société politique en Angleterre. Paris, 2003; Rome et l'État moderne européen / éd. par J.-P. Genet, Rome, 2007.

2 The colloquium devoted to the phenomenon coup d état was held in Madrid, in November, 25-27, 2002. Its materials were published: Coups d'État à la fin du Moyen Âge? Aux fondements du pouvoir politique en Europe occidentale / sous la dir. de F. Foronda, J.-P. Genet, J. M. Nieto Soria. Colloque international (2527 novembre 2002) Madrid, 2005 (Collection de la Casa de Velázquez. Vol. 91). 
It is known that the concept of coup détat emerged in 1639 in the treatise by Gabriel Naudé "Considerations politiques sur les coups d'Etat", in which a ruler violates norms and regulations for the sake of public interests. In the same text, besides coup détat, the concept of "raison détat" appeared, which is defined as "knowledge or science about the necessary means for establishing the seigneury, its preservation and expansion"3. The combination of two elements, which emphasized new understanding of the functions and possibilities of supreme power, in the same text brought about an appreciable breach between old and new concepts of commonwealth, and inevitable contradictions.

Traditional statist concept was criticized from two perspectives. On the one hand, it had become evident that the state of the $19^{\text {th }}$ century, absolute monarchies of the $15-18^{\text {th }}$ cc., feudal monarchies of the Middle Ages and ancient Roman Empire occupied physically different space. Thus, modern man encounters with the state on a daily basis: by paying taxes, interacting with public officers, using state property, receiving information about the state from the mass media. The subjects of the Early Modern monarchy encountered the supreme power or its attributes far less frequently, whereas the people inhabiting Western Europe in the time from Antiquity to late Middle Ages might not have seen representatives of the emperors and kings throughout their entire life. Recognizing the continuity between forms of political structures in European society, over the course of, at least, three thousand years, French scholars suggested that a separate period be identified which they entitled "new state" (état moderne). État moderne was formed as a result of the transformation of the feudal state in the $13-18^{\text {th }}$ centuries, and since then has been characterized by a number of distinct features differentiating État moderne from the previous political constructs.

On the other hand, there was essential criticism leveled at terminological analysis. In most European languages the word "state" is derived from Latin "status". This Latin term has been long used to describe power relations (for example, General States and Pays détats), however, in its modern sense (as the structure of supreme power relations in the human community, i.e. "the state") it emerged in the texts of the end of the $15-$ beginning of the $16^{\text {th }}$ century, with "The Prince" by Machiavelli being its most prominent example. Prior to it, such terms as "regnum" ("kingdom" or "realm"), "imperium" ("empire"), "civitas" ("polis") had been used. These terms often coexisted within the same text (for instance, in "The Defender of Peace" by Marsilius of Padua), and until the middle of the $20^{\text {th }}$ century researches and translators had treated them as full synonyms ${ }^{4}$. Later, the falsehood of this approach became more evident. Neither "regnum", nor "imperium", "civitas" or even "res publica" had the same scope of meaning as the modern concept of "status", and mere replacing them with "state" engendered serious notional distortions.

Machiavelli's usage of the word "status" (Italian "stato") was not accidental and stemmed from his own experience: he witnessed the formation of political entities in Northern Italy (named "city-states", nowadays obsolete), whose structure was entirely

${ }^{3}$ Definition of coup d'état : "excessus juris communis propter bonum commune", in other words, "courageous and extraordinary actions, which Sovereigns are forced to take in complex and often desperate situations, against common law, not conforming to any order or jurisdiction, which poses risk to the private for the sake of the public". - Naudé G. Considerations politiques sur les coups d'Etat. [S.1.], 1723. P.77.

${ }^{4}$ It was reflected in the English translation of the treatise "The Defender of Peace" by Marsilius of Padua made by A. Gewirth. The translator almost everywhere rendered Latin "regnum" and "civitas" with the English word "state". See: Marsilius of Padua. Defensor pacis / transl. and intr. by A. Gewirth. New York, 2001. 
new, and old "political vocabulary" 5 was not sufficient to describe them. Presuming that the emergence of phenomena precedes the emergence of concepts, it was concluded that by at least the end of the $15^{\text {th }}$ century there had existed états modernes in the north of the Apennine peninsula. Surprisingly rapid spread of the term "status" in other political texts from different European regions over the course of the next two centuries attests that the new concept found fertile ground as medieval structures of power were dying out with the terminology suitable for their description, yielding to "État moderne".

Having proven the necessity and usefulness of the concept of "État moderne" and having established the difference between this political phenomenon and preceding structures of powers, historians addressed the issue of its genesis. État moderne originated in the feudal society in the process of its sophistication which led to the emergence and differentiation of two spheres: the sphere of law and political sphere ${ }^{6}$. External conditions for both processes (or, perhaps, external manifestations) were, first of all, increasingly active interest in Roman Law in the $12-13^{\text {th }}$ centuries, and the development of civil, canon and common laws on its basis in accordance with the demands of the contemporary society; secondly, reception of political Aristotelianism, translation of his main works from Latin (in particular, "Politics" and "The Nicomachean Ethics") and application of his terminology and framework of categories to description of relations of power. Before that time, the power of one person over another (i.e. worldly, secular power) was not deemed worthy of philosophical reflection. There had been fragmentary contemplations, without a specially formed discourse.

In retrospect, it is possible to point out the following understandings of "pre-statist" concepts of power in Western Europe during the Middle Ages?. First and foremost, it is the theological concept of divine origin of earthly power connected with the name of Augustine and his work "The City of God". The next concept in the order of importance is the feudal concept of power, according to which, sovereign plays the role of supreme seigneur, whereas his relationships with the subjects take the form of contract agreement. The third concept associates supreme power with the military leader, while the sovereign is the defender and commander. Finally, it is necessary to mention the concept of kinship (patriarchal concept), in accordance with which the ruling dynasty is perceived as the oldest clan within the system of clans, with its ruler being the eldest clansman within his family. It should be noted that "pre-statist" concepts of power were not simplistic or ineffective: they had coexisted and functioned for more than seven centuries (since the period of late Roman Empire up to the $15^{\text {th }}$ century), and their impact is still felt in political reflections. All four "pre-statist" concepts left room for the possibility of serious changes (including forcible ones) in the structure of power relations. According to Augustine, "bad ruler" is the "scourge of the Lord" imposed on people for their sins, however, from the perspective of the ruler, tyranny is, obviously, a sin, blatant violation of Christian precepts. Therefore, tyranny fighters could expect theological justification of their actions. As far as

${ }^{5}$ Boucheron P. Théories et pratiques du coup d'État dans l'Italie princière du Quattrocento // Coups d'État à la fin du Moyen Âge? Aux fondements du pouvoir politique en Europe occidentale. Madrid, 2005. P. 25.

${ }^{6}$ Genet J.-P. Le Coup d 'État, ou les légitimités contrariées? // Coups d'État à la fin du Moyen Âge? Aux fondements du pouvoir politique en Europe occidentale. Madrid, 2005. P. 13.

7 Ladero Quesada M. A. Golpes de Estado a fines de la Edad Media? Fundamentos del poder político en la Europa occidental // Coups d'État à la fin du Moyen Âge? Aux fondements du pouvoir politique en Europe occidentale. Madrid, 2005. P. 598. 
feudal concept is concerned, tyranny is the breach of contract drawn up with the vassals, and the right to a just rebellion against an autocratic senior was taken for granted for a long time. Within the framework of the military concept, a "bad ruler" is ineffective commander who is unable to maintain discipline in his army. In accordance with the kinship concept, a ruler who violates family traditions is bad. In this case, those who bring him down appeal to an older relative. If there was no such living relative, then they appealed to the memory of the dead ancestors. Since the $13-14^{\text {th }}$ century the figure of "bad ruler" had started to be perceived within legal and political categories, and it was this perspective

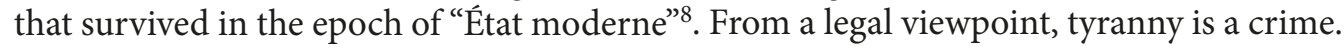
Tyranny fighters had to find legal norms which the ruler, who they intended to depose, had violated. Politically, tyranny is ineffective realization of power. Therefore, success in the actions against power structures politically justified the actions. Legal and political definitions of "tyranny" formed the basis for implementing coups détat.

In addition to the new concept of "bad ruling" during the epoch of État moderne, the power structure itself had undergone changes, new subjects of power relations had emerged - the ruler and his subjects. All the subjects comprised "political community" (universitas civium or res publica) ${ }^{9}$. Within the new context, the ruler (sovereign) had lost theological features, and his essence had been desacralized. Aristotelian political theory, or, rather, its reconsideration suggested by Western European intellectuals of the $13-16^{\text {th }}$ centuries, apparently contributed to it. The treatise «The Defender of Peace" by Marsilius of Padua was indicative in this respect. According to it, the ruler is "the main part" (pars principans) of civil corporation (universitas civium) and is subject to "the human legislator" (legislator humanus) ${ }^{10}$, who is the same as civil corporation, thereby, in other words, it is the entirety of all citizens ${ }^{11}$.

The period of the genesis of État moderne was the epoch of disappearance of old power structures, the time of crisis. The former ties had died out before the new ones strengthened. Under new circumstances, rulers became vulnerable and had to come up with new methods of defense of their power. These methods can also be divided into two groups: political and legal. Political strategy of the rulers during the emergence of État moderne involved incorporating noblemen into political sphere, with its depersonification at the same time. As the significance of feudal contracts was diminishing, the sacred status of sovereigns was disappearing, their military and dynastical authority was undergoing changes, the nobility deemed themselves less and less bound by the duties before the supreme power.

In the actual fact, it was the aristocracy who possessed real power resources: socio-economic (land tenure), legal (seigneurial court) and military (local nobility clientelism). It was quite frequent in the history of Western Europe that coalitions of noblemen against the royal power were formed, and civil wars became a common feature. France in $16-17^{\text {th }}$ centuries can exemplify it with its protracted Religious wars caused by the crisis of

8 Nieto Soria J.M. Rex inutilis y tiranía en el debate político de la Castilla bajomedieval // Coups d'État à la fin du Moyen Âge? Aux fondements du pouvoir politique en Europe occidentale. Madrid, 2005. P. 88.

9 Ladero Quesada M. A. Golpes de Estado... P.599-600.

${ }^{10}$ Marsilius de Padua. Defensor pacis // Monumentis Germaniae Historicis, Fontes iuris germanici antique. Hannover, 1933. I. XV.2.

11 Ibid. I. XII. 3. 
the outdated system of relationships between the monarchy and aristocracy ${ }^{12}$. The strategy of the French monarchy can be succinctly described in the following way: during the first stage loyal noblemen, retaining all their existing privileges, were encouraged to carry out royal service, whereas disloyal aristocracy was physically destroyed whenever possible; during the second stage representatives of nobility were awarded state positions and generous economic compensations, while their military and legal authority was reduced; during the third stage hereditary nobility was actively weakened as titles were given to people from lower social strata (leading to a sort of inflation of titles), while bureaucracy had finally been separated from aristocracy. Political strategy of defending the power of sovereign in other Western European countries was similar.

As far as legal defense was concerned, it involved establishing the corpus of legal norms securing royal power and dynasty, i.e., ensuring its legitimacy. The legitimacy of modern state is based on its national sovereignty. This abstract legal concept exists owing to the regular political dialogue between power institutions and society. In democratic states, this dialogue can be held by two means - ordinary and extraordinary. An ordinary mechanism is realized through elections, an extraordinary one - through referendum. Thus, a coup détat is something unacceptable, outside the bounds of law, as in theory when the ruling elite, or even the constitution, ceases to meet the demands of the society, there are legal ways of changing them ${ }^{13}$. It should be noted that this structure is based on the legitimacy of the state, which, in its turn, is founded on national sovereignty. National sovereignty took its final shape in Europe only after First World War during the implementation of Versailles system in the form of The League of Nations. In some cases, it is possible to claim, although with essential caveats in mind, that a number of European states (France, Germany, the Russian Empire, Italy (to a certain event) looked upon national sovereignty as a cornerstone of their legitimacy in the $19^{\text {th }}$ century and even in the second half of the $18^{\text {th }}$ century, but no earlier than that. Prior to that, since the emergence of État moderne its legitimacy had been based on a complex combination of old "legitimacies" of supreme royal power (sacred, military, dynastic, feudal), in addition to new political and legal "legitimacies", which could be expressed in one phrase: "good ruling" realized in accordance with "law".

In the Early Modern time, there were no mechanisms of the dialogue between rulers and political communities. The absence of dialogue didn't mean the absence of conflict, therefore, the only remaining means of resolving such conflicts was political cataclysm (including a coup d'état), and it was absolutely ordinary and imperative in the existing framework at the time ${ }^{14}$.

In order to outline the main features of coups détat during the period of genesis of État moderne, it's necessary to systematize this phenomenon and to consider concrete examples of this classification. The most frequent form of coups détat, and historically the first one at the time, was usurpation, which was quite natural - as the power was physically represented in the body of the sovereign.

12 Constant J.-M. Limites des Études Descriptives et Qualitatives Clans Partis Nobiliaires et Politiques au Temps des Guerres de Religion // Genèse de l'état moderne: prélèvement et redistribution: actes du Colloque de Fontevraud, 1984. Paris, 1987. P. 175-185.

${ }^{13}$ Ladero Quesada M. A. Golpes de Estado... P. 597.

14 Genet J.-P. Le Coup... P. 14. 
Usurpation was imminent when the sovereign was unable to establish an effective dialogue with his subjects. Usurpation per se was not legitimate, so the concept of treason had been developed in the course of the centuries to secure the sovereign. However, it was possible to legitimize usurpation afterwards. Strategically, to resist such forms of coups d'état it was necessary to make the center of power more sophisticated so that taking control over the body of the ruler by itself was not a sufficient prerequisite for the success of the attempt of usurping power ${ }^{15}$. Such usurpations can be exemplified by a series of overthrowing of English kings in $14-15^{\text {th }}$ centuries. In 1327 Edward II was removed from power and afterwards killed by the order of his spouse Isabella and her lover Roger Mortimer. His removal in favour of his son Edward III was approved by the Parliament. Moreover, in 1330, Mortimer was executed. The dynasty had not been discontinued; the Parliament legitimized "cruel" actions against lawful ruler - it was a classic form of usurping power.

In 1399, Henry Bolingbroke, Duke of Lancaster, son of John of Gaunt and grandson of Edward III overthrew Richard II and became King Henry IV. The events of 1327 inspired him as a model, setting a sort of precedent. However, the situation in that case was somewhat different: although Richard II was childless, he had a no less legitimate heir Edmund Mortimer (great-grandson of Edward III via female lineage, whose grandmother was the daughter of Duke of Clarence). For Bolingbroke's supporters, the task was to transform usurpation into a legal dynastic change causing the creation of a myth about Richard's willing abdication in favour of Henry. Contemporary public perception of this event was ambiguous, especially in comparison with the perception of usurpation in 1327. In this regard, the son of Henry IV - Henry V, upon ascending the throne, was compelled to transfer the body of the murdered Richard II to Westminster, thus making this action manifest that he was a lawful heir of the unfortunate monarch.

Despite the popularity of Henry V, Duke of York in 1461, his long distance cousin, deposed his son Henry VI. Dukes of Yorks descended from the fourth son of Edward III via male lineage (Edmund of Langley), and Duke of Clarence via - female lineage. Therefore, they had dynastic rights to claim the English throne, but the situation in 1461was fundamentally different from 1399 as Henry VI had a son Edward. Furthermore, deposition of Henry VI was not approved by the Parliament, and the city assembly of London ("people of London") proclaimed Duke of York King.

These examples enable to trace the evolution of the phenomenon of usurpation. In all these cases there were two aspects: political (deposition was put down to "bad ruling") and dynastic, which, in essence, was legal (debates about the order of seniority among certain branches of the dynasty). While dynastic aspect prevailed in 1327, as Edward III was the son and legitimate heir of Edward II, in the usurpation of 1461, when the Yorks' claims to the throne were very doubtful, it was political aspect that came to the fore.

The policy of the Tudors was the outcome of the series of usurpations in $14-15^{\text {th }}$ centuries, which was brought about by the fear of the continuation of the Wars of the Roses (starting after the events of 1461): the Tudors made their center of power more sophisticated to prevent or complicate attempts at usurpation ${ }^{16}$.

15 Watts J. Usurpation in England. A Paradox of State-Growth // Coups d'État à la fin du Moyen Âge? Aux fondements du pouvoir politique en Europe occidentale. Madrid, 2005. P. 115-130.

16 Ibid. P. 126. 
The second form of coups d'état typical of the period of the genesis of État moderne were extraordinary actions in the course of dynastic crises. They can be illustrated by the process of solving the issues of royal inheritance in Castile after the death of Her Catholic Majesty Isabel ${ }^{17}$.

In 1504, according to the will of Isabel, her daughter Joanna became Queen. Since Joanna suffered from a mental illness, she could be only a nominal monarch, so her father, Ferdinand, King of Aragon, was appointed her regent. However, at the time Joanna was married to Philip from the House of Habsburg. Castilian Cortes regarded Ferdinand's regency as a threat to their independence, so they proclaimed Philip regent in 1506, but shortly afterwards he died leaving an heir - minor Carlos. Thus, the struggle for the regency between Ferdinand of Aragon and the father of Philip, Emperor Maximilian, ensued. Due to the complexity of the military circumstances in Italy, Maximilian was forced to waive his claims, and in 1509, a treaty of Blois was concluded, according to which Ferdinand became regent for Joanna, and in the case of her death - for Carlos until his $25^{\text {th }}$ birthday. This treaty was acknowledged by Castilian Cortes. In 1516, Ferdinand died, and Castile was deprived of a legally capable ruler, which brought about a political crisis. Carlos was an "heir to the throne", i.e. the figure without any real power, whereas there was no elder relative left who might become regent for insane Joanna. Cardinal Cisneros took charge of the kingdom, making Carlos King within a short period. He initiated negotiations with the Roman Curia, as a result of which, in 1517, Pope Leo X issued the bull "Pacificus et aeternus Rex" where Carlos was named "Hispaniarum rex" ("Spanish king" without division into Castile, Aragon and Navarre) and "Rex catolicus" ("Catholic Majesty"). Both titles were reserved for Carlos, his prospective spouse and their heirs, while Joanna was mentioned as "Queen of Castile". Having obtained the sanction from the Church, Cisneros summoned Cortes of Castile. In 1518, after Cardinal's death Cortes swore allegiance to Carlos as King of Castile and Catholic Majesty ("Rex catolicus") in Valladolid. The ideological myth, in accordance to which Carlos inherited the title "Rex catolicus" and kingdoms of Castile, Aragon and Navarre directly from his grandfather and grandmother, leaving out his mother, was created. Resolving this dynastic crisis by extraordinary means, albeit without any violence, was a coup d'état, i.e. illegitimate seizure (transfer) of power, with its subsequent legitimation.

The third form of coups détat in the period of the genesis of État moderne were coups disguised as the struggle against conspiracy. A bright example of this form were events occurred after the assassination of Galeazzo Maria Sforza in $1476^{18}$. The Duke of Milan was stabbed on the $26^{\text {th }}$ of December by a group of conspirators during mass in the church of Santo Stefano. His murderers were immediately caught and executed. They were young patricians dissatisfied with the despotic power of Galeazzo Maria. However, his energetic son not only managed to retain the father's power, but also created a new political environment where there was no room for the ancient nobility of Milan. A similar example can be found in the history of Florence after the unsuccessful Pazzi conspiracy ${ }^{19}$. In April, 26, 1478, members of the Pazzi family and their allies attempted to assassinate Lorenzo and Giuliano de' Medici. As in Milan, the plotters aimed at preserving their former social role and authority, preventing "mutazione di stato" which undermined their social might.

17 Ladero Quesada M. A. Golpes de Estado... P. 595-606.

18 Boucheron P. Théories... P. 29.

19 Ibid. P. 30-33. 
There was a certain ritual logic behind the conspiracy: public attempt at the body of the sovereign (personal vengeance) and secret seizure of the Signoria (political act). Despite the death of Giuliano, the failure of the Pazzi gave free rein to Lorenzo, who succeeded in completing the process of establishing autocratic power of the Medici in Florence, which had been initiated a few decades before by his grandfather Cosimo.

Coups détat of this type were instrumental not only in setting up the regime of personal power: on the contrary, Venetian oligarchy eradicated the remains of monarchical competences of the Doges in the $14^{\text {th }}$ century by creating the Council of Ten - an extraordinary tribunal, whose functions involved control over the supreme Magistrates of Venice in order to prevent their usurping of full power, rather than political control over the population. It should be noted that the Council of Ten came into being after conspiracies organized by Tiepolo-Querini (1310) and Marino Faliero (1355), which had been brought about by the gradual process of the Great Council Lockout at the end of the XIII century (from that moment on, the membership was available only to a limited number of families, whereas others were excluded from real political activity). All of the above-mentioned conspiracies were not regarded as coups d'état, however, the mere fact of the existence of the Council of Ten had been deemed a "permanent coup d'etat" in the historiography until the end of the $18^{\text {th }}$ century ${ }^{20}$.

In the examples of coups détat of the third type listed above, conspirators turned out to be true defenders of the "state", they tried to prevent far-reaching political consequences, while their failures signified victory of so-called "creeping coups détat" on the part of the rulers.

Based on the classification described in the paper, it is possible to define key attributes of "coups détat":

- Inseparable connection with law and politics - legitimation of new "good ruling"

- Violence was often part of coups détat, but not necessarily its sine qua non.

- The aim and the outcome of a coup d'état - taking control of the entire political structure (hence assassinations of sovereigns and their literal, physical "capture").

- Sovereigns themselves acted as protagonists in some coups détat.

- Coup détat - is not necessarily an instantaneous or short-term event: it can last for quite a long time.

\section{References}

Boucheron P. Théories et pratiques du coup d'État dans l'Italie princière du Quattrocento. Coups d'État à la fin du Moyen Âge? Aux fondements du pouvoir politique en Europe occidenta. Éds F. Foronda, J.-P. Genet, J. M. Nieto Soria. Madrid, Velázquez Publ., 2005, pp. 19-50.

Constant J.-M. Limites des Études Descriptives et Qualitatives Clans Partis Nobiliaires et Politiques au Temps des Guerres de Religion. Genèse de l'état moderne: prélèvement et redistribution: actes du Colloque de Fontevraud, 1984. Éds J.-P. Genet, M. Le Mené. Paris, Éd. du Centre national de la recherche scientifique Publ., 1987, pp. 175-185.

État et Église dans la Genèse de l’État Moderne. Éds J.-P. Genet, B. Vincent. Madrid, Velázquez Publ., 1986, $312 \mathrm{p}$.

Genet J.-P. La Genèse de l'État modern Culture et société politique en Angleterre. Paris, Presses Universitaires de France, 2003, 332 p.

Genet J.-P. Le Coup d'État, ou les légitimités contraries. Coups d'État à la fin du Moyen Âge? Aux fondements du pouvoir politique en Europe occidentale. Éds F. Foronda, J.-P. Genet, J. M. Nieto Soria. Madrid, Velázquez Publ., 2005, pp. 1-18.

20 Ibid. P. 34-35. 
Ladero Quesada M.A. Golpes de Estado a fines de la Edad Media? Fundamentos del poder político en la Europa occidental. Coups d'État à la fin du Moyen Âge? Aux fondements du pouvoir politique en Europe occidentale. Éds F. Foronda, J.-P. Genet, J. M. Nieto Soria. Madrid, Velázquez Publ., 2005, pp. 595-606.

La Ville, la Bourgeoisie et la Genèse de l'État Moderne XIIe - XVIIIe siècles: actes du colloque de Bielefeld, 29 novembre $-1^{\text {er }}$ décembre 1985. Éds J.-P. Genet, N. Bulst. Paris, Éd. du Centre national de la recherche scientifique Publ., 1988, 254 p.

L'État Moderne et les Élites, XIIIe - XVIIIe siècles. Apports et limites de la méthode Prosopographique. Éds J.-P. Genet, G. Lottes. Paris, Publications de la Sorbonne Publ., 1996, 488 p.

L'État Moderne: Genèse, bilans et perspectives. Éd. par J.-P. Genet. Paris, Éd. du Centre national de la recherche scientifique Publ., 1990, 352 p.

L'État moderne: le droit, l'espace et les formes de l'État. Éds J.-P. Genet, N. Coulet. Paris, Éd. du Centre national de la recherche scientifique Publ., 1990, 236 p.

Naudé G. Considerations politiques sur les coups d'État. [S.l.], [s.n.], 1723, 252 p.

Nieto Soria J. M. Rex inutilis y tiranía en el debate político de la Castilla bajomedieval. Coups d'État à la fin du Moyen Âge? Aux fondements du pouvoir politique en Europe occidentale. Éds F. Foronda, J.-P. Genet, J. M. Nieto Soria. Madrid, Velázquez Publ., 2005, pp. 73-90.

Rome et l'État Moderne européen. Éd. par J.-P. Genet. Rome, École française de Rome Publ., 2007, 444 p.

Visions sur le développement des Etats Européens. Théories et historiographies de l'État Moderne. Éds J.P. Genet, W. Blockmans. Rome, École française de Rome Publ., 1993, 336 p.

Watts J. Usurpation in England. A Paradox of State-Growth. Coups d'État à la fin du Moyen Âge? Aux fondements du pouvoir politique en Europe occidentale. Éds F. Foronda, J.-P. Genet, J. M. Nieto Soria. Madrid, Velázquez Publ., 2005, pp. 115-130.

Received: 16.04.2018

Accepted: 31.05.2018 